\title{
Penerapan Sistem Penilaian Kinerja Dengan Intervening Motivasi Dan Kepuasan Kerja Terhadap Kinerja Karyawan
}

\author{
Frans Firsta Ferdiane $^{1 *}$, Sri Wahyu Lelly Hana Setyanti ${ }^{2}$, Sudaryanto ${ }^{2}$ \\ ${ }^{1}$ Program Magister Manajemen, Fakultas Ekonomi dan Bisnis,Universitas Jember \\ ${ }^{2}$ Fakultas Ekonomi dan Bisnis, Universitas Jember \\ *fransfirstaferdiane@gmail.com
}

\begin{abstract}
Performance appraisal system aims to guide the employee in achieving company's goals. The objective of this study are : 1) to directly analyze the effectiveness of performance appraisal system in influencing work satisfaction, work motivation, and employee performance; 2) to directly analyze the effectiveness of work satisfaction and work motivation in influencing employee performance;3) to indirectly analyze the effectiveness of performance appraisal system in influencing employee performance through work motivation and work satisfaction as the intervening variables. Performance appraisal system is implemented only to the employees with superior position in a company, not to those who are subordinates. Thus, the promotion is not targeted to the individual with the biggest contribution in the process of achieving company's goals. Primary data are collected by distributing questionnaires to the respondents using purposive sampling technique. The sample are consisted of 110 employees of the engineering division at Wringinanom Sugar Factory, Indonesia. Data are analyzed by Structural Equation Modeling (SEM). Results of the study show that the performance appraisal system has a direct and significant effect on work satisfaction, work motivation, and employee performance, and it has an indirect significant effect on employee performance through work motivation and work satisfaction as the intervening variables.
\end{abstract}

Keywords: Employee Performance, Motivation, Performance Appraisal System, Work Satisfaction,

https://doi.org/10.26905/jmdk.v6i1.2090

\section{PENDAHULUAN}

Pada perkembangan jaman saat ini, komponen sumber daya manusia adalah faktor penentu utama dalam pengelolaan suatu perusahaan. Selain pengembangan teknologi secara terus menerus, perusahaan juga perlu untuk mengelola sistem organisasinya secara optimal dan terpadu sehingga dapat mendukung tercapainya visi dan misi perusahaan. Salah satu bentuk nyata aplikasi manajemen sumber daya manusia di perusahaan yaitu adanya penerapan sistem penilaian terhadap hasil kinerja karyawan.
Sistem penilaian kinerja yang diaplikasikan pada karyawan bertujuan agar visi dan misi perusahaan dapat dipahami dan lebih mudah dicapai oleh masing-masing karyawan. Pada Pabrik Gula Wringin Anom sudah memiliki sistem penilaian kinerja pada karyawan pimpinan yang diperoleh pada hasil kerja sebagai poin penilaian, bukan dari proses usaha penyelesaian suatu target perusahaan, sehingga ketercapaian suatu target tidak jelas berasal dari hasil kerja sebagian karyawan atau hasil kerja tim. Hal ini ditunjukan jika ada suatu pekerjaan dengan target waktu 
tertentu yang mendapat poin penilaian saat pekerjaan selesai hanya pimpinan pekerjaan saja yaitu karyawan pimpinan saja. Pencapaian target perusahaan berdampak pada peningkatan kinerja Pabrik dengan berdasarkan penilaian tiap-tiap karyawan yang turut serta dalam tim pelaksana pekerjaan. Dengan adanya peningkatan kinerja pabrik maka pemberian penghargaan berupa promosi, insentif, dan peningkatan gaji. Pemberian penghargaan berdasarkan poin penilaian masing-masing karyawan. Namun kondisi nyata yang terjadi di lapangan saat target perusahaan tercapai, pemberian penghargaan hanya sebatas karyawan pimpinan saja dan belum menyeluruh ke semua anggota tim yang ikut serta dalam pekerjaan tersebut.

Sistem penilaian kinerja dilakukan sesuai dengan pencapaian hanya pada level karyawan pimpinan saja dan tidak sampai karyawan pelaksana, sehingga jika terdapat promosi jabatan karena pencapaian target tidak menunjukan individu mana yang paling berkontribusi terhadap kesuksesan suatu pekerjaan tersebut. Contoh kasus tersebut dapat membuat karyawan pelaksana menjadi tidak puas terhadap hasil pekerjaannya dan kurang termotivasi untuk melaksanakan pekerjaan yang baru/berikutnya kemudian pada akhirnya akan terjadi penurunan kinerja karyawan tersebut. Dampak lain yang timbul dari kejadian tersebut adalah mengakibatkan turunnya kinerja pabrik.

Berdasarkan fenomena-fenomena yang ada tersebut diduga bahwa penerapan sistem penilaian kinerja pada Pabrik Gula Wringin Anom tidak efektif. Hal ini ditunjukan dengan anggapan subjek penilaian hanya pada karyawan pimpinan saja yang terkesan subjektif dan cenderung sekedar formalitas, selain itu pemberian penghargaan setelah penilaian tidak berjalan dengan semestinya, sehingga perlu adanya evaluasi dan analisis agar sistem penilaian kinerja dapat berjalan dengan semestinya dan tujuan utama perusahaan dapat tercapai. Penelitian ini penting dilakukan karena penerapan sistem penilaian kinerja secara tidak efektif dapat merugikan perusahaan baik jangka pendek maupun jangka panjang. Menurut Fletcher (2001), suatu penilaian kinerja adalah pendekatan strategis yang mengintegrasikan antara kepentingan kebijakan organisasi dan kegiatan sumber daya manusia. Sedangkan menurut Taylor et al., (2011) sistem penilaian kinerja menjadi gagal dikarenakan adanya reaksi dan konflik serta ketidakpuasan dan ketidakadilan yang dialami karyawan

Menurut Flippo (1995:177), motivasi adalah suatu teknik keahlian dalam mengarahkan seorang pegawai dan sebuah organisasi agar dapat bekerja supaya berhasil dalam menggapai suatu tujuan dari organisasi tersebut. Wulandari (2013) meneliti bahwa sistem penilaian kinerja terhadap kinerja karyawan melalui kepuasan kerja dapat berpengaruh secara tidak langsung pada karyawan. Menurut Setiyawan, B., \& Waridin (2006), kinerja karyawan adalah hasil atau prestasi kerja karyawan yang dinilai dari segi kuantitas maupun kualitas berdasarkan prosedur standar operasional yang ditentukan oleh pihak perusahaan. Sedangkan menurut Robbins (2010:35) faktor-faktor yang dapat digunakan untuk meningkatkan hasil kinerja karyawan diantaranya adalah motivasi dan kepuasan kerja.

Beberapa penelitian tentang pengaruh kepuasan kerja dan motivasi terhadap kinerja (Umar, 2012; Grant, 2001; Wibowo, 2013). Menurut Grant (2001), motivasi bertindak sebagai kekuatan pendorong yang mengarahkan karyawan terhadap tujuannya. Murdianto (2013) meneliti bahwa sistem penilaian kinerja dapat mempengaruhi secara positif terhadap motivasi kerja karyawan.

Penelitian ini dilakukan pada Pabrik Gula Wringin Anom di situbondo Propinsi Jawa Timur. Adapun tujuan penelitian ini adalah: menganalisis efektifitas sistem penilaian kinerja dalam mempengaruhi motivasi kerja dan kepuasan kerja karyawan; menganalisis efektifitas motivasi kerja dan kepuasan kerja dalam mempengaruhi kinerja karyawan, dan menganalisis efektifitas sistem penilaian kinerja dalam mempengaruhi kinerja dengan intervening motivasi kerja pada karyawan, menganalisis efektifitas 
sistem penilaian kinerja dalam mempengaruhi kinerja dengan intervening kepuasan kerja karyawan, pada Pabrik Gula Wringin Anom.

\section{METODE}

Penelitian ini adalah penelitian yang menggunakan pendekatan secara kuantitatif dimana bertujuan untuk mengetahui tingkat pengaruh sistem penilaian kinerja dalam mempengaruhi kinerja karyawan dengan variabel intervening berupa motivasi dan kepuasan kerja di Pabrik Gula Wringin Anom. Penelitian ini dilaksanakan di Pabrik Gula Wringin Anom Situbondo.

Populasi yang digunakan pada penelitian ini adalah seluruh karyawan pelaksana bagian teknik Pabrik Gula Wringin Anom yang memiliki status Karyawan Tetap, Karyawan PKWT (Perjanjian Kerja Waktu Tertentu), Karyawan Borongan dan Karyawan Outsourcing sejumlah 110 pekerja. Teknik analisis yang digunakan adalah Structural Equation Modeling (SEM) dengan menggunakan program AMOS (Analysis of Moment Structure) versi 22.0.

\section{HASIL DAN PEMBAHASAN \\ Hasil}

Analisis Structural Equation Modelling

Hasil pengujian data dengan program AMOS versi 22.0 memberikan hasil model SEM seperti terlihat pada Gambar 1 berikut :

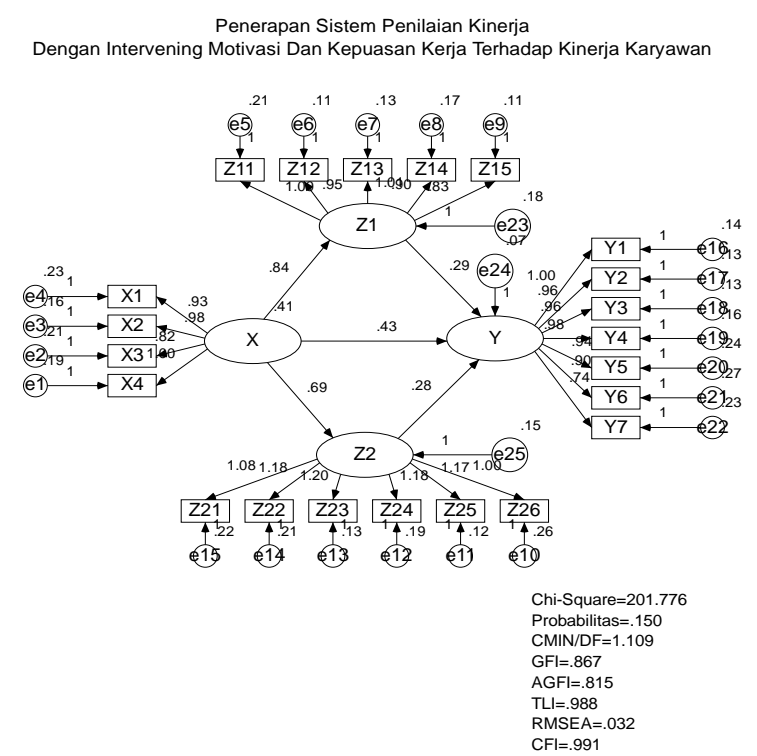

Gambar 1. Hasil Analisis SEM

Sumber: Data diolah
Selanjutnya dari hasil pengujian kesesuian model penelitian, maka langkah berikutnya adalah menguji kausalitas yang dikembangkan dalam penelitian tersebut. Dari model yang sesuai, maka diinterpretasikan masing-masing koefisien jalur tersebut. Pengujian nilai koefisien jalur secara rinci disajikan dalam tabel 1 berikut.

Tabel 1. Hasil Uji Kausalitas

\begin{tabular}{cccccccc}
\hline \multicolumn{2}{c}{ Pengaruh } & Est. & S.E. & C.R. & P & Ket. \\
\hline Z1 & $<--$ & X & 0,845 & 0,109 & 7,76 & 0 & Sig. \\
Z2 & $<--$ & X & 0,693 & 0,1 & 6,913 & 0 & Sig. \\
Y & $<--$ & X & 0,433 & 0,124 & 3,477 & 0 & Sig. \\
Y & $<--$ & Z1 & 0,286 & 0,094 & 3,026 & 0 & Sig. \\
Y & $<--$ & Z2 & 0,275 & 0,102 & 2,7 & 0,01 & Sig. \\
\hline
\end{tabular}

Sumber: Data diolah

\section{Pembahasan \\ Pengaruh Sistem Penilaian Kinerja terhadap Motivasi Kerja}

Hasil pengujian koefisien jalur untuk besar pengaruh Sistem Penilaian Kinerja (X) terhadap Motivasi Kerja (Z1) memiliki jalur positif dengan nilai sebesar 0,845 dan nilai C.R sebesar 7,760 serta nilai probabilitas (p) sebesar 0,000 yang memiliki arti bahwa Sistem Penilaian Kinerja (X) berpengaruh signifikan terhadap Motivasi Kerja (Z1). Sehingga hipotesis yang menyatakan bahwa sistem penilaian kinerja berpengaruh secara signifikan terhadap motivasi kerja karyawan terbukti kebenarannya atau $\mathrm{H} 1$ diterima. Hasil penelitian ini sejalan dengan hasil penelitian Sarbini Wono dan Surachman (2008), dimana suatu sistem penilaian kinerja dapat berpengaruh secara positif dan signifikan terhadap motivasi kerja pekerja.

\section{Pengaruh Sistem Penilaian Kinerja terhadap Kepuasan Kerja.}

Hasil pengujian koefisien jalur untuk besar pengaruh Sistem Penilaian Kinerja (X) terhadap Kepuasan Kerja (Z2) memiliki jalur positif dengan nilai sebesar 0,693 dan nilai C.R sebesar 6,913 serta nilai probabilitas (p) sebesar 0,000 yang berarti bahwa Sistem Penilaian Kinerja (X) berpengaruh signifikan terhadap Kepuasan kerja (Z1). Sehingga hipotesis yang menyatakan bahwa sistem 
penilaian kinerja berpengaruh secara signifikan terhadap kepuasan kerja karyawan terbukti kebenarannya atau H2 diterima. Hasil penelitian ini di dukung dengan pendapat Hasibuan (2003:88) bahwa penerapan penilaian kinerja bertujuan untuk meningkatkan tingkat kepuasan kerja karyawan melalui pengakuan terhadap hasil kerja karyawan tersebut. Karyawan merasa puas dengan dengan penerapan sistem penilaian kinerja ketika ada kepercayaan dari pengawas dan umpan balik dari hasil penilaian, khususnya di bidang pengembangan keterampilan, pay for performance (Whiting, et. al, 2007). Hasil penelitian ini mendukung hasil penelitian Dwipayana (2015), bahwa penerapan sistem penilaian kinerja berpengaruh secara positif dan signifikan terhadap kepuasan kerja.

\section{Pengaruh Motivasi Kerja terhadap Kinerja Karyawan}

Hasil pengujian koefisien jalur untuk besar pengaruh Motivasi Kerja (Z1) terhadap Kinerja Karyawan (Y) memiliki jalur positif dengan nilai sebesar 0,286 dan nilai C.R sebesar 3,026 serta nilai probabilitas (p) sebesar 0,002 yang memiliki arti bahwa Motivasi Kerja (Z1) berpengaruh signifikan terhadap Kinerja Karyawan (Y). Sehingga hipotesis yang menyatakan bahwa motivasi kerja berpengaruh secara signifikan terhadap kinerja karyawan terbukti kebenarannya atau H3 diterima. Mangkunegara (2011:61) mengemukakan bahwa sikap mental karyawan yang pro dan positif terhadap situasi kerja dapat meningkatkan motivasi kerja dalam dirinya untuk mencapai hasil kinerja maksimal. Hasil penelitian ini mendukung hasil penelitian Umar (2012), bahwa semakin tinggi motivasi kerja seorang karyawan maka cenderung berpengaruh terhadap peningkatan kinerja karyawan.

\section{Pengaruh Kepuasan Kerja terhadap Kinerja Karyawan}

Hasil pengujian koefisien jalur untuk besar pengaruh Kepuasan Kerja (Z2) terhadap Kinerja Karyawan (Y) memiliki jalur positif dengan nilai sebesar 0,275 dan nilai C.R sebesar 2,700 serta nilai probabilitas (p) sebesar 0,007 yang memiliki arti bahwa Kepuasan Kerja (Z2) berpengaruh secara signifikan terhadap Kinerja Karyawan (Y). Sehingga hipotesis yang menyatakan bahwa kepuasan kerja berpengaruh signifikan terhadap kinerja karyawan terbukti kebenarannya Hasil penelitian ini mendukung hasil penelitian Umar (2012), bahwa semakin tinggi peningkatan motivasi kerja karyawan, cenderung berpengaruh terhadap peningkatan kinerja karyawan.

\section{Pengaruh Sistem Penilaian Kinerja terhadap Kinerja Karyawan}

Hasil pengujian koefisien jalur untuk besar pengaruh Sistem Penilaian Kinerja (X) terhadap Kinerja Karyawan (Y) memiliki jalur positif dengan nilai sebesar 0,433 dan nilai C.R sebesar 3,477 serta nilai probabilitas (p) sebesar 0,000 yang berarti bahwa Sistem Penilaian Kinerja (X) berpengaruh secara signifikan terhadap Kinerja Karyawan (Y). Sehingga hipotesis yang menyatakan bahwa Sistem Penilaian Kinerja Terhadap Kinerja karyawan terbukti kebenarannya atau H5 diterima. Dessler (2003:321) berpendapat bahwa penilaian kinerja adalah proses evaluasi seorang karyawan baik saat ini maupun dimasa lalu yang didasarkan dengan standar kinerja dari karyawan tersebut. Hasil dari suatu penilaian kinerja dapat menunjukkan apakah karyawan tersebut telah memenuhi tuntutan yang dikehendaki perusahaan, baik dilihat dari sisi kualitas maupun kuantitas. Dengan adanya mekanisme penilaian kinerja maka akan dapat diketahui bagaimana tugas dan tanggung jawab dari seorang karyawan dapat terlaksana serta seberapa jauh hasilnya dalam memenuhi standar yang telah ditentukan.

\section{Pengaruh Sistem Penilaian Kinerja dengan Intervening Motivasi Kerja terhadap Kinerja Karyawan}

Berdasarkan hasil perhitungan statistik dengan menggunakan SEM dapat diketahui bahwa ada pengaruh yang signifikan sistem penilaian kinerja terhadap motivasi kerja. Hasil statistik juga menunjukkan bahwa ada 
pengaruh yang signifikan motivasi kerja terhadap kinerja karyawan. Sedangkan pengaruh sistem penilaian kinerja terhadap kinerja karyawan berdasarkan hasil statistik juga signifikan. Kesimpulan dari analisis ini maka Ho ditolak dan Ha diterima. Sehingga hipotesis yang menyatakan bahwa sistem penilaian kinerja dengan intervening motivasi kerja berpengaruh signifikan terhadap kinerja karyawan di Pabrik Gula Wringinanom terbukti kebenarannya atau H6 diterima. Hasil penelitian ini sejalan dengan pendapat Dessler (2003:321), penilaian kinerja adalah proses evaluasi seorang karyawan baik saat ini maupun dimasa lalu yang didasarkan dengan standar kinerja dari karyawan tersebut. Hasil dari suatu penilaian kinerja dapat menunjukkan apakah karyawan tersebut telah memenuhi tuntutan yang dikehendaki perusahaan, baik dilihat dari sisi kualitas maupun kuantitas.. Hasil penelitian ini mendukung hasil penelitian Gunawan (2015) dan Budiman (2011), bahwa penerapan sistem penilaian kinerja berpengaruh secara positif terhadap motivasi kerja untuk peningkatan kinerja. Sistem Penilaian Kinerja yang baik tentunya akan menghasilkan penilaian yang positif dari pegawai. Dengan adanya penerapan penilaian kinerja maka para bawahan mendapatkan perhatian dari atasan sehingga mendorong mereka bergairah bekerja. Karyawan dengan motivasi yang tinggi dapat bekerja dengan sesuai prosedur sehingga pencapaian tujuan yang telah ditetapkan dapat tercapai akan meningkatkan kinerja karyawan.

\section{Pengaruh Sistem Penilaian Kinerja dengan Intervening Kepuasan Kerja terhadap Kinerja Karyawan}

Berdasarkan hasil perhitungan statistik dengan menggunakan SEM dapat diketahui bahwa ada pengaruh yang signifikan sistem penilaian kinerja terhadap motivasi kerja. Hasil statistik juga menunjukkan bahwa ada pengaruh yang signifikan motivasi kerja terhadap kinerja karyawan. Sedangkan pengaruh sistem penilaian kinerja terhadap kinerja karyawan berdasarkan hasil statistik juga signifikan. Kesimpulan dari analisis ini maka Ho ditolak dan Ha diterima. Sehingga hipotesis yang menyatakan bahwa sistem penilaian kinerja dengan intervening kepuasan kerja berpengaruh signifikan terhadap kinerja karyawan di Pabrik Gula Wringinanom terbukti kebenarannya atau H7 diterima. Hasil penelitian ini sejalan dengan pendapat Hasibuan (2003:88) bahwa penerapan penilaian kinerja bertujuan untuk meningkatkan tingkat kepuasan kerja karyawan melalui pengakuan terhadap hasil kerja karyawan tersebut. Antara kepuasan kerja dapat menyebabkan meningkat kinerja pegawai, sebaliknya kinerja yang baik dapat menyebabkan kepuasan kerja (Setiyawan dan Waridin, 2006).

\section{Kesimpulan}

Berdasarkan hasil penelitian, maka dapat diambil beberapa kesimpulan yaitu sistem penilaian kinerja berpengaruh signifikan terhadap motivasi kerja karyawan pelaksana. Hal ini ditunjukan oleh pihak manajemen menerapkan penilaian yang bebas dari unsur subjektif dan nepotisme, poin-poin yang digunakan dalam penilaian mudah dipahami dan dapat diterima karyawan karena sesuai dengan budaya kehidupan karyawan, serta poin-poin yang digunakan dalam penilaian sesuai dengan tolak ukur yang jelas berdasarkan beban pekerjaan dan tingkat kesulitan pekerjaan.

\section{DAFTAR PUSTAKA}

Budiman, Immanuel Frans. 2011. Pengaruh Sistem Pengukuran Kinerja Dan Sistem Penghargaan Terhadap Kinerja Manajerial Dengan Motivasi Sebagai Variabel Intervening (Studi Empiris Pada Bank Umum Di Jember). Skripsi. Jember: Universitas Jember.

Dessler, Gary. Human Resource Management. New Jersey: Prentice Hall, 2003

Dwipayana, Arif Defi 2015. Penerapan Sistem Penilaian Kinerja; Dampaknya Terhadap Kepuasan Dan Stres Kerja Karyawan PT. Aerofood Indonesia Unit Aerofood Acs Denpasar (Garuda 
Indonesia Group). Tesis. Bali: Pascasarjana Universitas Udayana.

Fletcher Clive., 2001. Performance Appraisal and Management. Journal of Occupational and Organizational Psychology. Vol 74. Issues 4. pp. 473487

Flippo, E. B. 1995. Manajemen Personalia. Edisi ke-6. Jilid I. Jakarta: Erlangga.

Gunawan, T A. 2015. Pengaruh sistem penilaian kinerja dengan motivasi dan kepuasan kerja sebagai variabel intervening dapat mempengaruhi kinerja karyawan di PG wilayah timur PT Perkebunan Nusantara XI (Persero). Tesis. Surabaya: Program Pasca Sarjana Universitas Airlangga.

Grant, K. e. 2001. The Role of Satisfaction with Territory Design on The Motivation, Attitudes, and Work Outcomes of Salesperson. Journal of The Academy of Marketing Sciences. 165-178.

Hasibuan, Malayu SP. 2003. Manajemen Sumber Daya Manusia. Edisi revisi. Jakarta: Bumi Aksara.

Mangkunegara, A.A Anwar Prabu. 2006. Evaluasi Kinerja SDM. Bandung: Refika Aditama.

Murdianto, Asrini Mutiarasari. 2013. Pengaruh Sistem Penilaian Kinerja Terhadap Motivasi Karyawan Kantor Pusat PT Infomedia Nusantara Di Jakarta. Skripsi. Bandung: Universitas Telkom.

Robbins, Stephen P., Mary Coulter. 2010. Manajemen. Edisi Kesepuluh. Jakarta : Erlangga.

Setiyawan, B., \& Waridin. 2006. Pengaruh Disiplin Kerja Karyawan Dan Budaya Organisasi Terhadap Kinerja Di Divisi Radiologi RSUP Dokter Kariadi. JRBI Vol 2 No. 2 Hal: 181-198.

Taylor, Selvarajan TT and Cloninger Peggy A, 2011. Can Performance Appraisal
Motivate Employees to Improve Performance? A Mexican Study. The International Journal of Human Resources Management. Vol.1. No.22. pp. 1- 22

Umar, Akmal. 2012. Pengaruh Upah, Motivasi Kerja, dan Kepuasan Kerja terhadap Kinerja Pekerja pada Industri Manufaktur di Kota Makassar. Jurnal Aplikasi Manajemen Vol 10 No. 2.

Wibowo. 2013. Perilaku Dalam Organisasi. Jakarta: Raja Grafindo Persada.

Wono, Sarbini \& Surachman. 2008. Pengaruh Sistem Penilaian Kinerja dan Keterbukaan Nilai Kinerja Terhadap Motivasi Kerja (Kasus Pekerja Bottom Line di Perusahaan Rokok PT. "G"). Jurnal Manajemen Dan Kewirausahaan Vol.10, No. 1 Hal: 1819.

Wulandari, Rita Dwi. 2013. Hubungan Sistem Penilaian Kinerja dengan Kepuasan Kerja dan Kinerja Karyawan (Studi kasus pada PT. Harum Kayu Lestari). Skipsi. Jember: Universitas Muhammadiyah. 